\title{
PENGARUH GAYA KEPEMIMPINAN DAN BUDAYA ORGANISASI PADA KINERJA GURU DENGAN MOTIVASI SEBAGAI VARIABEL INTERVENING
}

\author{
Aurelia Dewanggi H.P. \\ Hunik Sri Runing Sawitri \\ Fakultas Ekonomi dan Bisnis Universitas Sebelas Maret
}

\begin{abstract}
Purpose of this study to analyze the effects of leadership style, organizational culture on motivation and performance of senior high school techers in Wonogiri. Job performance is very necessary for any profession. Job performance of teacher increasingly organizational performance so that purpose of company or organization can be reachable. Many factors which can increase job/activity such as leadership style, organizational culture, and motivation. How far leadership style and organizational culture influence to job performance is tested in this research, by insert motivation as intervening variables.

Test utilized to analyze leadership style and organizational culture influence to job performance that is path analysis, $R^{2}$ test, as well as statistic $T$ test, and direct and inderct effect. Research data obtained from questionary answer propagated to the teacher of senior high school in Wonogiri. Result of research analysis express that leadership style and organizational culture has positive influence and significant to teachers job performance. And Motivation proof to be intervening variabel in relationship beetwen leadership style and organizational culture to teachers job performance.
\end{abstract}

Keywords: leadership style, organizational culture, motivation, performance, teacher

\section{ABSTRAK}

Tujuan penelitian ini untuk menganalisis pengaruh gaya kepemimpinan, budaya organisasi terhadap motivasi dan kinerja guru SMA di Wonogiri. Prestasi kerja sangat diperlukan untuk profesi apa pun. Meningkatnya kinerja kerja guru dapat semakin meningkatkan kinerja organisasi sehingga tujuan perusahaan dapat dicapai. Banyak faktor yang dapat meningkatkan pekerjaan/kegiatan seperti gaya kepemimpinan, budaya organisasi, dan motivasi.

Pengaruh gaya kepemimpinan dan budaya organisasi terhadap kinerja pekerjaan diuji pada penelitian ini, dengan memunculkan motivasi sebagai variabel intervening. Uji yang digunakan untuk menganalisis gaya kepemimpinan dan pengaruh budaya organisasi terhadap kinerja dengan motivasi sebagai variabel intervening yaitupathanalysis, uji t, uji $R^{2}$, serta pengaruh langsung dan tidak langsung. Data penelitian diperoleh dari jawaban daftar pernyataan yang disebarkan kepada guru SMA di Wonogiri. Hasil analisis penelitian mengungkapkan bahwa gaya kepemimpinan dan budaya organisasi berpengaruh positif dan signifikan terhadap kinerjaguru. Dan 
motivasi memiliki peranan sebagai variabel intervening dalam hubungan antara gaya kepemimpinan dan budaya organisasi pada kinerja guru.

Kata kunci: gaya kepemimpinan, budaya organisasi, motivasi, kinerja, guru.

Organisasi merupakan kesatuan sosial yang dikoordinasikan secara sadar, dengan sebuah batasan yang relatif dapat diidentifikasi, bekerja secara terus menerus untuk mencapai tujuan (Robbins, 2001). Secara eksplisit, definisi tersebut mengasumsikan kebutuhan untuk mengkoordinasikan pola interaksi manusianya. Pola interaksi sumberdaya manusia dalam organisasi harus diseimbangkan dan dikembangkan agar organisasi dapat tetap eksis.

Salah satu keberhasilan dalam mengembangkan managemen organisasi adalah dengan adanya pemberdayaan sumberdaya manusia. Pendidikan merupakan salah satu organisasi yang berperan menyiapkan sumberdaya manusia.Sejalan dengan perkembangan zaman, tantangan yang dihadapi sistem pendidikan semakin meningkat baik secara kualitas maupun kuantitas. Untuk menjalankan pendidikan dibutuhkan tenaga-tenaga pengajar yang kompeten. Guru menjadi faktor sentral dalam sistem pendidikan di sekolah karena pelaksanaan kurikulum dan adanya interaksi untuk menyalurkan pengetahuan dilakukan oleh guru.

Peranan guru sangat penting dalam mentransformasikan input pendidikan, sehingga dapat dipastikan bahwa di sekolah tidak akan ada perubahan atau peningkatan kualitas tanpa adanya perubahan dan peningkatan kualitas guru. Kinerja guru diharapkan dapat mendongkrak kualitas dan relevansi pendidikan, dalam implementasinya di lapangan.

Budaya organisasi adalah pola asumsi dasar yang diciptakan, ditemukan atau dikembangkan oleh kelompok tertentu saat mereka menyesuaikan diri dengan masalah-masalah eksternal dan integrasi internal yang telah bekerja cukup baik serta dianggap berharga, dan karena itu diajarkan pada anggota baru sebagai cara yang benar untuk menyadari, berpikir, dan merasakan hubungan dengan masalah tersebut (Luthans, 2005).

\section{Peningkatan kinerja guru juga} membutuhkan pengelolaan dan pengendalian pada berbagai subsistem dalam organisasi agar tetap konsisten dengan target yang ingin dicapai organisasi. Karena itu dibutuhkan seorang pemimpin karena pemimpin merupakan bagian penting dalam peningkatan kinerja para pekerja.

Wonogiri memiliki 20 Sekolah Menengah Atas, terdiri dari 12 sekolah negeri dan 8 sekolah swasta. Sekolah Menengah Atas di Wonogiri pada umumnya saat ini berusaha untuk meningkatan kinerja guru dalam mengelola kegiatan pembelajaran agar dapat berhasil dengan maksimal. Total ada 743 guru SMA baik swasta maupun negeri. Hasil pembelajaran di sekolah atas menjadi tolak ukur pula dalam seleksi masuk perguruan tinggi. Karena itu kinerja dari guru perlu diperhatikan dan diperlukan adanya informasi yang aktual tentang kondisi kemampuan guru dalam mengelola kegiatan pembelajaran di lembaga tersebut. Aspek-aspek yang berkaitan dengankepemimpinan, budaya organisasi yang belum mantap, dan peningkatan motivasi menjadi sebuah agenda yang perlu segera ditangani.

Dari apa yang telah dikemukakan, penulis melakukan penelitian mengenai bagaimana faktor gaya kepemimpinan, budaya organisasi dan motivasi guru mempengaruhi kinerja organisasi. Penelitian ini mengacu pada penelitian yang dilakukan oleh Sokro (2012) yang menunjukkan adanya hubungan signifikan antara budaya organisasi, motivasi, dan kinerja karyawan pada perusahaan multinasional di Ghana dan penelitian dari Mulyanto dan Arif Yunanato (2014) yang 
menunjukkan adanya pengaruh positif dan signifikan pada gaya kepemimpinan, budaya organisasi, komitmen organisasi terhadap motivasi dan kinerja pegawai BKD Klaten.

\section{TELAAH PUSTAKA}

\section{Gaya Kepemimpinan}

Karyadi (2002) menyebutkan bahwa kepemimpinan didefinisikan sebagai suatu kepribadian yang mendatangkan keinginan suatu kelompok untuk menirunya atau mengikutinya, atau memancarkan pengaruh tertentu sebagai suatu kewibawaan yang membuat kelompok orang untuk melakukan perbuatan yang dikehendaki.

Menurut Thoha (2001) gaya kepemimpinan adalah salah satu cara yang dipergunakan seorang pemimpin dalam mempengaruhi perilaku orang lain. Sedangkan menurut Stoner, Freeman, dan Gilbert (1996) menyatakan bahwa gaya kepemimpinan adalah berbagai pola tingkah laku yang disukai oleh pemimpin dalam proses mengarahkan dan mempegaruhi pekerja.

Davis (1994) menyatakan bahwa gaya kepemimpinan adalah pola tindakan pemimpin secara keseluruhan seperti yang dipersepsikan oleh pegawainya. Gaya kepemimpinan merupakan karakteristik manajer-manajer inti dalam mencapai sasaran perusahaan atau dengan kata lain lebih menujuk pada pola perilaku eksekutif puncak dan tim manajemen senior. Menurut teori yang dikembangkan Robert House dalam Robbins (2001), terdapat 4 macam gaya kepemimpinan, yaitu :

1. Kepemimpinan Direktif

2. Kepemimpinan Suportif

3. Kepemimpinan Partisipatif

4. Kepemimpinan yang berorientasi pada pencapaian

\section{Budaya Organisasi}

Budaya organisasi adalah suatu sistem makna bersama yang dianut oleh anggota yang membedakan organisasi itu dengan organisasi lain, yang merupakan seperangkat karakteristik utama yang dihargai oleh organisasi itu (Robbins, 2001). Edgar Schein dalam Fred Luthans (2005) menyatakan bahwa budaya organisasi adalah pola asumsi dasar yang diciptakan, ditemukan atau dikembangkan oleh kelompok tertentu saat mereka menyesuaikan diri dengan masalahmasalah eksternal dan integrasi internal yang telah bekerja cukup baik serta dianggap berharga, dan karena itu diajarkan pada anggota baru sebagai cara yang benar untuk menyadari, berpikir, dan merasakan hubungan dengan masalah tersebut.

Motivasi

Teori motivasi pada dasamya berakar pada kebutuhan yang disusun berdasarkan prioritas kekuatan kebutuhan yang dimiliki manusia. Menurut Maslow (Suradinata, 1996) mengemukakan tentang kebutuhan, yaitu manakala kebutuhankebutuhan pada tingkat bawah telah dipenuhi, maka upaya manusia untuk melakukan sesuatu pada tingkat yang lebih tinggi lebih mudah yaitu untuk memenuhi kebutuhan-kebutuhan yang lebih tinggi.

Pengertian motivasi berasal dari kata motif yang artinya sesuatu yang mendorong dari dalam diri seseorang untuk melakukan sesuatu (gerakan), sedangkan motivasi adalah sesuatu yang membuat orang untuk bertindak atau berperilaku dalam cara-cara tertentu yang didasarkan dari motif (Suradinata, 1996).

Faktor-faktor yang mempengaruhi motivasi manusia (Suradinata, 1996), yaitu:

1. Kebutuhan manusia

2. Dorongan dan disiplin

3. Penghargaan

4. Lingkungan

5. Pencapaian tujuan.

\section{Kinerja}

Menurut Prawirosentono (2003) kinerja adalah hasil kerja yang dapat dicapai oleh seseorang atau sekelompok orang dalam suatu organisasi, sesuai dengan wewenang dan tanggung jawab masing-masing, dalam rangka upaya mencapai tujuan organisasi bersangkutan secara legal, tidak melanggar hukum dan 
sesuai dengan moral maupun etika.

Menurut Mas'ud (2004) kinerja adalah hasil pencapaian dari usaha yang telah dilakukan yang dapat diukur dengan indikator-indokator tertentu. Variabel kinerja karyawan diukur melalui tujuh indikator, yaitu:

1. Kualitas kerja,

2. Efisiensi

3. Kemampuan karyawan

4. Ketepatan waktu

5. Pengetahuan karyawan

6. Kreativitas

7. Melaksanakan tugas sesuai prosedur

\section{Gaya Kepemimpinan danMotivasi}

Stoner et al (1996) menyatakan bahwa gaya kepemimpinan adalah berbagai pola tingkah laku yang disukai oleh pemimpin dalam proses mengarahkan dan mempegaruhi pekerja. Sedangkan motivasi berasal dari kata motif yang artinya sesuatu yang mendorong dari dalam diri seseorang untuk melakukan sesuatu (gerakan), sedangkan motivasi adalah sesuatu yang membuat orang untuk bertindak atau berperilaku dalam cara-cara tertentu yang didasarkan dari motif (Suradinata,1996). Dari dua pengertian tentang kepemimpinan dan motivasi dapat ditarik suatu kesimpulan bahwa apabila kepemimpinan yang diterapkan dapat mendorong seseorang untuk bertindak atau berperilaku sesuai dengan tujuan organisasi. Hal ini sesuai dengan penelitian Mulyanto dan Yunanto (2014) yang menunjukkan bahwa gaya kepemimpinan berpengaruh pada motivasi.

\section{H1. Gaya Kepemimpinan berpengaruh postif dan signifikan pada motivasi}

\section{Budaya Organisasi danMotivasi}

Robbins (2001) secara spesifik mengemukakan sejumlah peranan penting yang dimainkan oleh budaya organisasi dalam suatu perusahaan, antara lain, membantu menciptakan rasa memiliki jati diri bagi karyawan, dapat dipakai untuk mengembangkan keikatan pribadi dengan perusahaan, membantu stabilisasi perusahaan sebagai suatu sistem sosial dan menyajikan pedoman perilaku, sebagai hasil dari norma-norma perilaku yang sudah terbentuk, apabila hal ini terwujud, maka karyawan akan didorong melakukan aktivitas berdasar nilai- nilai diatas, hal ini akan mempengaruhi motivasi. Nilai- nilai yang ada diatas sebagai budaya organisasi, apabila ditingkatkan perannya maka akan semakin tinggi motivasi karyawan. Penelitian dari Sokro (2012) menunjukkan adanya hubungan yang signifikan antara budaya organisasi dan motivasi kerja karyawannya. Budaya kerja yang kuat dapat menciptakan motivasi dan meningkatkan pada kinerja karyawan.

\section{H2. Budaya Organisasi berpengaruh postif dan signifikan pada motivasi}

\section{Gaya Kepemimpinan danKinerja

$$
\text { Menurut Hasibuan }
$$

kepemimpinan merupakan suatu cara yang ditempuh seorang pemimpin untuk mempengaruhi perilaku bawahan, agar mau bekerja sama dan bekerja secara produktif untuk mencapai tujuan organisasi. Sedangkan kinerja adalah hasil atau tingkat keberhasilan seseorang secara keseluruhan selama periode tertentu di dalam melaksanakan tugas dibandingkan dengan berbagai kemungkinan, seperti standar hasil kerja, target, atau sasaran atau kriteria yang telah ditentukan terlebih dahulu dan telah disepakati bersama (Rivai \& Basri, 2004). Hal ini juga sesuai dengan hasil penelitian dari Mulyanto dan Yunanto (2014) yang menunjukkan bahwa gaya kepemimpinan memiliki pengaruh positif dan signifikan pada kinerja karyawan BKD Klaten. Dari uraian tersebut dapat ditarik hipotesis sebagai berikut:

\section{$H_{3}$. Gaya Kepemimpinan berpengaruh postif dan signifikan pada kinerja}

Budaya Organisasi danKinerja

Roh dalam sebuah organisasi adalah budaya organisasi, mempunyai peranan yang sangat penting bagi tercapainya tujuan organisasi yang diinginkan. 
Perilaku dari para pegawai yang telah terbentuk, maka akan menimbulkan budaya organisasi yang baik pula. Budaya organisasi yang baik akan dapat meningkatkan kinerja para pegawai. Hal ini sesuai dengan Mulyanto dan Yunanto (2014) juga menunjukkan adanya pengaruh budaya kerja terhadap kinerja karyawan BKD Klaten. Dari uraian tersebut dapat ditarik hipotesis sebagai berikut:

\section{$\mathrm{H}_{4}$. Budaya organisasi berpengaruh postif dan signifikan pada kinerja}

Motivasi danKinerja

Herzberg dalam Buchari (2000)

menyatakan ada dua (2) faktor yang mempengaruhi motivasi kerja, yakni faktor intrinsik dan faktor ekstrensik. Faktor intrinsik, seperti : hasil yang dicapai ( prestasi ), pengakuan diri, kerja itu sendiri dan tanggung jawab, serta kemajuan dan pertumbuhan. Faktor ekstrensik, seperti kebijakan dari pimpinan organisasi, penyeliaan/ pengawasan, hubungan antar pribadi dan kondisi kerja serta gaji yang sesuai. Komponen berpengaruh pada kinerja, semakin baik faktor-faktor motivasi akan berpengaruh pada peningkatan kinerja. Penelitian Sokro (2012) yang menunjukkan motivasikerja karyawanmempengaruhiefisiensi

keseluruhanorganisasidanmotivasimenent ukanpotensi kinerjakaryawan. Dari uraian tersebut dapat ditarik hipotesis sebagai berikut:

\section{H5. Motivasi berpengaruh postif dan signifikan pada kinerja}

Motivasi berperan sebagai variabel intervening antara Gaya Kepemimpinan dan Kinerja

Yeh dan Hong (2012) melakukan penelitian tentang Pengaruh Komitmen Organisasi sebagai variabel Mediasi pada Tipe Kepemimpinan dan Kinerja. Hasil penelitian tersebut menjelaskan bahwa komitmen organisasi memegang pengaruh mediasi parsial antara hubungan gaya kepemimpinan dan prestasi kerja. Mulyanto dan Yunanto (2014) menunjukkan hasil bahwa motivasi memiliki peran dalam memediasi gaya kepemimpinan dan kinerja karyawan. Dari uraian tersebut dapat ditarik hipotesis sebagai berikut:

\section{$H_{6}$ : Motivasi memiliki peran sebagai variabel intervening pada hubungan antara gaya kepemimpinan dan kinerja}

Motivasi berperan sebagai variabel
intervening antara budaya
organisasi dan Kinerja
Motivasi akan meningkatkan produktivitas seseorang apabila memiliki kemampuan untuk menyelesaikan tugas dan pekerjaannya. Lingkungan kerja dan budaya yang berlangsung dapat memotivasi seseorang untuk meningkatkan kinerjanya. Menurut hasil penelitian dari Mulyanto \& Yunanto (2014) variabel kinerja dipengaruhi oleh motivasi sebagai variabel intervening kepemimpinan dan budaya kerja karyawan di kantor BKD Klaten. Dari uraian tersebut dapat ditarik hipotesis sebagai berikut:

H7 : Motivasi memiliki peran sebagai variabel intervening pada hubungan antara budaya organisasi dan kinerja 


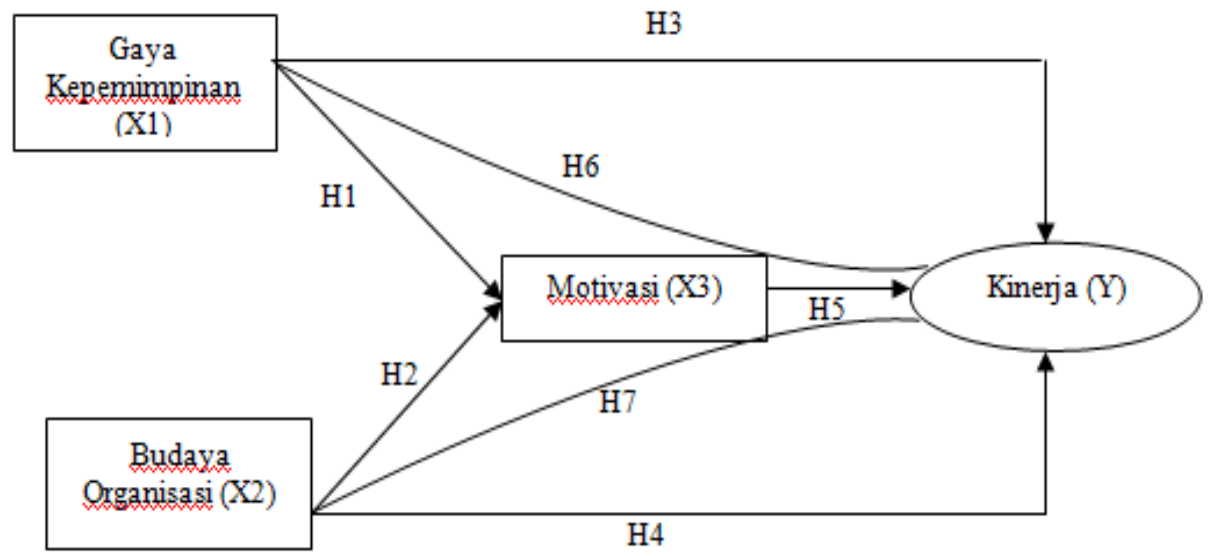

Gambar 1. Kerangka Pemikiran

Sumber: Dimodifikasi dariSokro (2012), Mulyanto dan Yunanto (2014).

\section{METODE PENELITIAN}

\section{Jenis dan Sumber Data}

Tipe penelitian yang digunakan adalah jenis eksplanatori dengan pendekatan survei. Penelitian ini termasuk penelitian sampel dalam kategori data kuantitatif dimana suatu pertanyaan memerlukan alternatif jawaban, sangat setuju, setuju, netral, kurang setuju, dan sangat tidak setuju. Penilaian jawaban dengan, menggunakan skala likert, di mana jawaban sangat setuju diberi nilai angka 5 , setuju 4, netral 3 , kurang setuju 2 , dan sangat tidak setuju 1.Sumber data penelitian ini terbagi menjadi dua yaitu data primer dan data sekunder. Data primer yaitu data yang diperoleh langsung dari guru SMAdi Kabupaten Wonogiri yang menjadi responden penelitian ini melalui penyebaran kuesioner. Data Sekunder diperoleh dari studi pustaka seperti literatur/sumber lain yang ada hubungannya dengan penelitian.

\section{Obyek dan Lokasi penelitian}

Obyek penelitian adalah Guru di SMA di Kabupaten Wonogiri. Lokasi penelitian di SMA Kabupaten Wonogiri.

\section{Populasi dan Sampel}

Populasi yang dimaksud dalam penelitian ini adalah guru di SMA Kabupaten Wonogiri. Jumlah sekolah negeri di Wonogiri sebanyak 12 dan sekolah swasta sebanyak 8 sekolah. Dari 20 Sekolah Menengah Atas di Wonogiri guru yang mengajar ada sejumlah 754 orang. Dengan jumlah populasinya terhitung, maka dalam penentuan sample digunakan rumus Slovin sebagai berikut:

$$
\begin{aligned}
& n=\frac{754}{1+754 .(0.1)^{2}} \\
& n=88.14
\end{aligned}
$$

Jadi jumlah sample yang diperoleh sebanyak 88 guru sebagai responden penelitian.Metode pengambilan sampel dalam penelitian ini adalah convenience sampling merupakan teknik dalam memilih sampel, peneliti tidak mempunyai pertimbangan lain kecuali berdasarkan kemudahan saja.

\section{Variabel Penelitian}

Variabel yang digunakan dalam penelitian ini yaitu Gaya Kepemimpinan dan Budaya Organisasisebagai variabel independen dan Kinerja Guru sebagai variabel dependen. Motivasi sebagai variabel intervening

\section{HASI L DAN PEMBAHASAN}

\section{Uji Validitas}

Pengujian validitas dilakukan pada empat variabel utama dalam penelitian ini, yaitu gaya kepemimpinan, budaya organisasi, motivasi, dan kinerja. Tabel 1 menunjukkan nilai KMO Measure of 
Sampling Adequacy (MSA) dalam dengan Chi-squares signifikan pada 0,000 penelitian ini sebesar 0,790. Karena nilai dapat disimpulkan bahwa uji analisis faktor MSA di atas 0,5 serta nilai Barlett test ini dapat dilanjutkan.

Tabel 1. Uji Validitas KMO and Bartlett's Test

\begin{tabular}{|l|l|l|}
\hline $\begin{array}{l}\text { Kaiser-Meyer-Olkin } \\
\text { Adequacy. }\end{array}$ & Measure of Sampling & 0,681 \\
\hline $\begin{array}{l}\text { Bartlett's Test } \\
\text { Sphericity }\end{array}$ & of Approx. Chi-Square & 1636,579 \\
\hline & Df & 435 \\
\hline
\end{tabular}

Sumber: data primer yang diolah, 2015

\section{Uji Reliabilitas}

Dari Tabel2dapat dilihat hasil pengujian reliabilitas menunjukkan bahwa koefisiensi (r) alpha hitung seluruh variabel lebih besar dibandingkan dengan kriteria yang dipersyaratkan atau nilai kritis (role of tumb) sebesar 0,6 yaitu kepimimpinan, budaya organisasi, motivasi, dan kinerja guru masing-masing sebesar 0,$731 ; 0,724 ; 0,761$; dan $0,748>0,6$ sehingga dapat dikatakan bahwa butir-butir pertanyaan seluruh variabel dalam keadaan reliabel.

\section{Tabel 2. Hasil Uji Realibilitas}

\begin{tabular}{|l|c|c|}
\hline \multicolumn{1}{|c|}{ Variabel } & Cronbach's Alpha & Hasil \\
\hline Gaya kepemimpinan & 0,731 & Reliabel \\
\hline Budaya organisasi & 0,724 & Reliabel \\
\hline Motivasi & 0,761 & Reliabel \\
\hline Kinerja & 0.748 & Reliabel \\
\hline
\end{tabular}

Sumber: daya primer yang diolah, 2015

\section{Uji Hipotesis}

\begin{tabular}{|c|c|c|c|c|c|}
\hline \multirow{3}{*}{\multicolumn{3}{|c|}{ Variabel Independen }} & \multirow{2}{*}{\multicolumn{3}{|c|}{ Variabel Dependen: Motivasi }} \\
\hline & & & & & \\
\hline & & & Coeficient Beta & $\mathrm{t}$ & Sig \\
\hline \multicolumn{3}{|l|}{ Gaya kepemimpinan } & 0,387 & 3,830 & 0,000 \\
\hline \multicolumn{3}{|l|}{ Budaya Organisasi } & 0,273 & 2,697 & 0,008 \\
\hline F-sig & $=$ & 0,000 & & & \\
\hline Rsquare & $=$ & 0,323 & & & \\
\hline Adjusted R Square & $=$ & 0,308 & & & \\
\hline Signifikansi & $=$ & $5 \%$ & & & \\
\hline
\end{tabular}

Gaya Kepemimpinan dan budaya organisasi berpengaruh positif signifikan pada motivasi, ditunjukkan dengan nilai sig 0,000<0,05 dan 0,008<0,05. Artinya apabila gaya kepemimpinan dan budaya organisasi ditingkatkan maka motivasi akan meningkat. Nilai adjusted $\mathrm{R}^{2}$ sebesar 0,308 yang berarti bahwa $30,8 \%$ variabel motivasi dapat dijelaskan oleh variabel gaya kepemimpin dan dan budaya organisasi, sisanya sebesar $69,2 \%$ dijelaskan oleh variabel lain yang tidak diikutseratakan dalam penelitian ini.

Hasil Regresi Persamaan 2

\begin{tabular}{|l|l|l|l|}
\hline \multirow{2}{*}{ Variabel Independen } & \multicolumn{3}{|l|}{ Variabel Dependen: Kinerja } \\
\cline { 2 - 4 } & Coeficient Beta & t & Sig \\
\hline Gaya kepemimpinan & 0,426 & 4,935 & 0,000 \\
\hline Budaya Organisasi & 0,222 & 2,676 & 0,009 \\
\hline
\end{tabular}


Vol. 16, No. 1, 2016: 43 - 54

\begin{tabular}{|l|l|l|l|l|l|}
\hline Motivasi & $=$ & 0,000 & 0,286 & 3,351 & 0,001 \\
\hline F-sig & $=$ & 0,585 & & & \\
\hline Rsquare & $=$ & 0,570 & & \\
\hline Adjusted R square & $=$ & $5 \%$ & & \\
\hline Signifikansi & $=$ & & \\
\hline
\end{tabular}

Gaya kepemimpinan, budaya organisasi dan motivasi berpengaruh positif signifikan pada kinerja. Hal ini ditunjukkan dengan nilai signifikasi dari ketiga variabel < 0,05 . Nilai adjusted $R^{2}$ sebesar 0,507 yang berarti bahwa $50,7 \%$ variabel kinerja dapat dijelaskan oleh variabel gaya kepemimpin dan, budaya organisasi, dan motivasi sisanya sebesar 49,3\% dijelaskan oleh variabel lain yang tidak diikutseratakan dalam penelitian ini.

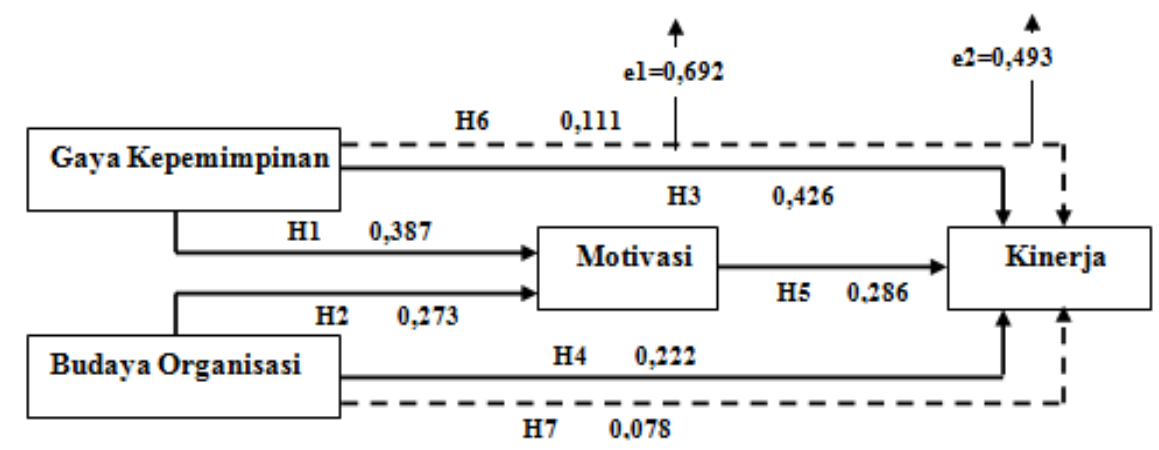

Keterangan:

Gambar 2. Pengaruh Langsung dan Tidak Langsung

\section{PEMBAHASAN}

\section{Pengaruh Gaya Kepemimpinan Pada Motivasi}

Hasil uji pada persamaan 1 menunjukkan bahwa variabel gaya kepemimpinan berpengaruh positif dan signifikan pada motivasi guru SMA di Wonogiri. maka hipotesis yang menyatakan kepemimpinan berpengaruh signifikan pada motivasi guru SMA di Wonogiri, atau hipotesis 1 didukung. Gaya Kepemimpinan yang efektif akan mampu mendorong motivasi guru sehingga produktifitas kinerja, loyalitas dan kepuasan meningkat. Dengan gaya kepemimpinan yang tepat, seorang pemimpin dapat mempengaruhi bawahnnya yang dapat menghasilkan motivasi bagi bawahannya.

Hasil penelitian ini mendukung penelitian yang dilakukan oleh Mulyanto dan Yunanto (2014) yang menunjukkan bahwa gaya kepemimpinan berpengaruh pada motivasi. Caraudin (2011) juga membuktikan adanya pengaruh positif antara kepemimpinan dengan kinerja guru dan cukup memotivasi kinerja guru.

\section{Pengaruh Budaya Organisasi Pada Motivasi \\ Hasil uji pada persamaan} menunjukkan bahwa variabel budaya organisasi berpengaruh positif dan signifikan pada motivasi guru SMA di Wonogiri. maka hipotesis 2 yang menyatakan budaya organisasi berpengaruhsignifikan padamotivasi guru SMA di Wonogiri didukung. Hal ini dikarenakan budaya organisasi dalam suatu perusahaan, dapat dipakai untuk mengembangkan keikatan pribadi dengan perusahaandan menyajikan pedoman perilaku, sebagai hasil dari norma-norma perilaku yang sudah terbentuk. Apabila hal ini terwujud, maka karyawan akan didorong melakukan aktivitas berdasar nilai- nilai diatas, hal ini akan mempengaruhi motivasi.

Hasil ini mendukung penelitian 
sebelumnya yang dilakukan oleh Penelitian dari Sokro (2012) menunjukkan adanya hubungan yang signifikan antara budaya organisasi dan motivasi kerja karyawannya. Budaya kerja yang kuat dapat menciptakan motivasi dan meningkatkan pada kinerja karyawan.

\section{Pengaruh Gaya Kepemimpinan Pada Kinerja Guru}

Hasil penelitian ini, membuktikan bahwa kepemimpinan berpengaruh positif dan signifikan pada kinerja guru maka hipotesis yang menyatakan kepemimpinan berpengaruh signifikan pada kinerja guru SMA di Wonogiri atau hipotesis 3didukung. Seorang pemimpin yang baik dapat menyampaikan informasi secara tepat dan mendorong karyawannya untuk mencapai target organisasi. Kemampuan memimpin bukan hanya dapt mempengaruhi secara individu tetapi juga menggerakan secara kelompok sehingga meningkatkan kinerja organisasi. Ini berarti bahwa gaya kepemimpinan yang baik dapat mendorong kinerja guru.

Hal ini juga sesuai dengan hasil penelitian dari Mulyanto dan Yunanto (2014) yang menunjukkan bahwa gaya kepemimpinan memiliki pengaruh positif dan signifikan pada kinerja karyawan BKD Klaten. Hasil penelitian dari Mutmainah dan Troena (2013) juga menunjukkan bahwa gaya kepemimpinan kepala sekolah juga secara signifikan dan positif mempengaruhi kinerja guru sekolah swasta Malang.

\section{Pengaruh Budaya Organisasi Pada Kinerja Guru}

Hasil uji pada persamaan 2 menunjukkan bahwa variabel budaya organisasi berpengaruh positif dan signifikan pada motivasi guru SMA di Wonogiri. maka hipotesis yang menyatakan budaya organisasi berpengaruh signifikan pada kinerja guru SMA di Wonogiri, atau hipotesis 4didukung.Budaya organisasi dapat membantu stabilisasi organisasi sebagai suatu sistem sosial dan menyajikan pedoman perilaku. Perilaku dari para pegawai yang telah terbentuk akan menimbulkan budaya organisasi yang baik pula. Budaya organisasi yang baik akan dapat meningkatkan kinerja para pegawai.

Hal ini sesuai dengan penelitian Waren dan Lena (2014) menunjukan hasil yang signifikan antara budaya organisasi dan kinerja guru. Hasil penelitian Mulyanto dan Yunanto (2014) juga menunjukkan adanya pengaruh budaya kerja terhadap kinerja karyawan BKD Klaten.

\section{Pengaruh Motivasi Pada Kinerja Guru}

Penelitian ini menunjukkan bahwa motivasi berpengaruh positif signifikan pada kinerja guru maka hipotesis yang menyatakan motivasi berpengaruh signifikan pada kinerja guru SMA di Wonogiri atau hipotesis 5didukung. Hal ini mengindikasikan bahwa semakin tinggi motivasi semakin tinggi kinerja guru.

Hasil penelitian ini mendukung penelitian Sokro (2012) yang menunjukkan motivasikerja karyawan mempengaruhi efisiensi keseluruhan organisasi dan motivasi menentukan potensi kinerjakaryawan.

\section{PeranMotivasi Sebagai Variabel Intervening Dalam Pengaruh Gaya Kepemimpinan Pada Kinerja}

Hasil penelitian menunjukkan bahwa motivasi memiliki peranan dalam memediasi pengaruh gaya kepemimpinan pada kinerja. Hasil ini menunjukkan bahwa gaya kepemimpinan yang tepat dapat mendorong motivasi guru untuk bekerja lebih baik dan sesuai dengan arahan pimpinannya. Sehingga kinerja guru pun akan semakin meningkat.

Hal ini sesuai dengan penelitian Yeh dan Hong (2012) yang melakukan penelitian tentang Pengaruh Komitmen Organisasi sebagai variabel Mediasi pada Tipe Kepemimpinan dan Kinerja. Hasil penelitian tersebut menjelaskan bahwa komitmen organisasi memegang pengaruh mediasi parsial antara hubungan gaya kepemimpinan dan prestasi kerja. Mulyanto dan Yunanto (2014) menunjukkan hasil bahwa motivasi memiliki peran dalam memediasi gaya kepemimpinan dan kinerja karyawan. 


\section{PeranMotivasi sebagai variabel intervening dalam pengaruh budaya organisasi pada kinerja}

Hasil penelitian menunjukkan

bahwa motivasi memiliki peran dalam memediasi pengaruh budaya organisasi pada kinerja. Hasil ini menunjukkan bahwa budaya organisasi yang dapar menciptakan kenyamanan dalam bekerja dapat mendukung karyawan menyelesaikan tugasnya dengan baik. Karyawan yang termotivasi dengan adanya lingkungan kerja yang sehat dan aman dapat meningkatkan produktivitas seseorang dalam bekerja.

Hal ini sesuai dengan hasil penelitian dari Mulyanto \& Yunanto (2014) variabel kinerja dipengaruhi oleh motivasi sebagai variabel intervening kepemimpinan dan budaya kerja karyawan di kantor BKD Klaten.

\section{SIMPULAN}

\section{Simpulan}

1. Gaya kepemimpinan dan budaya organisasi berpengaruh positif pada motivasi, dengan arti:

Gaya kepemimpinan yang diterapkan pada sekolah akan berpengaruh positif pada motivasi guru, demikian pulan dengan budaya organisasi yang ada pada SMA di Wonogiri akan berpengaruh positif pada motivasi guru. Semakin baik penerapan gaya kepemimpinan dan budaya organisasi pada SMA di Wonogiri maka tingkat motivasi akan semakin tinggi.

2. Gaya kepemimpinan dan budaya organisasi berpengaruh positif pada kinerja, dengan arti:

Gaya kepemimpinan yang diterapkan pada sekolah akan berpengaruh positif pada kinerja guru, demikian pula dengan budaya organisasi yang ada pada SMA di Wonogiri akan berpengaruh positif pada kinerja guru. Semakin baik penerapan gaya kepemimpinan dan budaya organisasi pada SMA di Wonogiri maka tingkat kinerja guru akan semakin tinggi.
3. Variabel motivasi memiliki peranan mediasi dalam hubungan antara gaya kepemimpinan pada kinerja guru, dengan arti:

Gaya kepemimpinan yang diterapkan dalam SMA di Wonogiri dapat mempengaruhi secara langsung kinerja guru, ataupun gaya kepemimpinan dapat mempengaruhi kinerja guru bila guru merasakan adanya motivasi dalam bekerja.

4. Variabel motivasi memiliki peranan mediasi dalam hubungan antara budaya organisasi pada kinerja guru, dengan arti:

Budaya organisasi yang ada dalam SMA di Wonogiri dapat mempengaruhi secara langsung kinerja guru, ataupun budaya organisasi dapat mempengaruhi kinerja guru bila guru merasakan adanya motivasi dalam bekerja.

\section{Keterbatasan}

1. Obyek penelitian dalam penelitian ini hanya sebagian kecil dari guru-guru di SMA Wonogiri, sehingga berdampak pada terbatasnya generalisasi penelitian. Dengan demikian untuk mengaplikasikan penelitian ini pada konteks yang berbeda diperlukan kehati-hatian dalam mencermati karakteristik yang melekat pada objek amatan studi.

2. Penelitian ini menggunakan metode survey melalui kuesioner, peneliti tidak terlibat langsung dalam aktivitas di SMA Wonogiri sehingga kesimpulan yang diambil hanya berdasarkan pada data yang dikumpulkan melalui instrumen secara tertulis.

3. Hasil penelitian ini hanya dapat dijadikan analisis pada obyek penelitian yang terbatas pada SMA di Wonogiri sehingga memungkinkan adanya perbedaan hasil penelitian dan kesimpulan apabila penelitian dilakukan pada objek penelitian yang berbeda dengan profesi yang berbeda pula. 
4. Penelitian ini hanya menggunakan variabel gaya kepemimpinan, budaya organisasi dan motivasi sebagai indikator dalam kinerja sehingga masih terdapat beberapa variabel lain yang berpengaruh terhadap kinerja guru.

\section{Saran}

1. Pimpinan SMA di Wonogiri diharapkan dapat meningkatkan kinerja dengan memantapkan tipikal kepemimpinan yang perlu dilakukan, misalnya kepemimpinan yang berkualitas adalah pimpinan yang dapat mengajak bawahannya untuk terlibat dalam pengambilan keputusan, membantu menyelesaikan masalah bawahannya, mempunyai komitmen terhadap tujuan, konsisten mengarahkan bawahan, mempunyai pengetahuan yang luas, menguasai bidang tugas yang dipimpinnya, dan mempunyai kedisiplinan yang tinggi dan memiliki keteladanan.

2. Upaya-upaya peningkatan budaya organisasi di SMA Wonogiri secara kongkrit, sebaiknya mensosialisasikan kondisi kerja yang kondusif, budaya yang berorientasi aktivitas, perilaku dalam bekerja secara profesional, pentingnya inovasi yang dilakukan oleh guru, dan pentingnya pengambilan resiko proporsional dalam bekerja.

3. Diperlukan upaya meningkatkan motivasi dengan cara memberikan suatu tantangan untuk kemajuan, memberikan dorongan untuk bekerjasama dengan rekan kerja, mengembangkan kelompok, dan mendorong agar guru-guru memastikan pekerjaan dilakukan sesuai dengan rencana belajar mengajar.

\section{DAFTAR PUSTAKA}

Buchari. 2000.Manajemen Sumber Daya Manusia. PT. Bumi Aksara: Jakarta

Caraudin. 2011. Pengaruh Kepemimpinan Kepala Sekolah dan Iklim Kerja Sekolah Terhadap Kinerja Guru.
Jurnal UPI Edu Edisi Khusus, No.2

Agustus 2011, hal.229-245.

Davis, Keith. 1994.Human Behavior At Work:Organizational Behavior. Grolier Incorporated.

Karyadi, M. 2002.Kepemimpinan. Bogor: Politea.

Luthans, Fred. 2005. Organizational Behavior. 7th Edition. Singapore: McGraw-Hill International Edition.

Mas'ud, Fuad. 2004.Survai Diagnosis Organisasional (Konsep dan Aplikasi). Badan Penerbit Universitas Diponegoro: Semarang.

Mulyanto, dan S. Hardaya. 2009. Pengaruh Motivasi, Kepuasan Kerja dan Komitmen Organisasi Terhadap Kinerja Pewagai Dinas Tenaga Kerja dan Transmigrasi Provinsi Daerah Istimewa Yogyakarta. Excellent, Vol. 1 No. 2, hal.123144.

Mulyanto, dan A. Yunanto. 2014. Pengaruh Gaya Kepemimpinan, Budaya Organisasi, Komitmen Organisasi Terhadap Motivasi Kerja dan Kinerja Pegawai BKD Klaten. Advance, Vol 1. No.2, hal. 55-62.

Mutmainah, dan E. Troena. 2013. Organizational Culture, Leadership Style Influence on Organizational Commitment and Performance of Teachers. International Journal of Business and Behavioral Sciences, Vol. 3No.10, p.54-65.

Prawirosentono, Suyadi. 2003. Manajemen

Sumber Daya Manusia: Kebijakan

Kinerja Karyawan. Yogyakarta: BPFE.

Rivai, V., dan A.F.M. Basri. 2004. Performances Appraisal Sistem Yang Tepat Untuk Menilai Kinerja Karyawan dan Meningkatkan Daya Saing Perusahaan. Jakarta: PT.Raja Grafindo Persada.

Robbins, Stephen. 2001. Perilaku Organisasi. Alih Bahasa Hadyana Pujaatmaka dan Benyamin Molan. Jakarta: Prenhallindo. 
Jurnal Bisnis \& $M$ anajemen

Vol. 16, N 0. 1, 2016: 43 - 54

Sokro, Evans. 2012. Analysis of The Relationship that Exist Between Organisational Culture, Motivation and Performance. Problems of Management in the 21st century. Volume 3, p.106-119

Suradinata, Ermaya. 1996. Psikologi Kepegawaian dan Peranan
Pimpinan Dalam Motivasi Kerja . Bandung: CV Ramadan.

Yeh, H., dan D. Hong. 2012. The Mediating Effect of Organizational Commitment on Leadership Type and Job Performance. The Journal of Human Resource and Adult Learning, Vol.50. p.50-59. 